\title{
Prevalence of the Two Variants of Mandibular Second Premolars in Kerala Population
}

\author{
Prevalencia de las Dos Variantes de Segundos \\ Premolares Mandibulares en Población Kerala
}

\author{
S. Sunil* \& Devi Gopakumar*
}

SUNIL, S. \& GOPAKUMAR, D. Prevalence of the two variants of mandibular second premolars in Kerala population. Int. J. Odontostomat., 6(3):375-377, 2012.

ABSTRACT: Mandibular second premolars, though generally are included under bicuspids, are of two types, the 2 cusp and 3 cusp varients. The aim was to determine the prevalence of the two varieties of mandibular second premolars in Kerala population, South India. This descriptive investigation was undertaken in two dental colleges of Kerala, India. A total of 2500 mandibular second premolars were examined for cuspal variations, groove patterns and gender predilection. A slight predilection (52.8\%) for 2-cusp variety was noticed. The most frequent occlusal configuration were crescent shaped and $Y$ groove patterns for 2 cusp and 3 cusp varieties of second premolars respectively.

KEY WORDS: mandibular second premolar, cusp forms, groove patterns.

\section{INTRODUCTION}

The mandibular second premolar, the fifth tooth from midline is the succedaneous tooth of deciduous mandibular second molar (Ash \& Nelson, 2009). Premolars, though generally grouped as bicuspids, mandibular premolars do not strictly follow the criteria. In mandibular first premolars, the lingual cusp is not functional and the second premolars are of two cusp and three cusp varieties (Fuller et al., 2001; Ludwig, 1957). In this study, we have probed the prevalence of the two varieties of mandibular second premolars in the state population.

\section{MATERIAL AND METHOD}

A total of 2500 mandibular second premolars were evaluated in this study. The subjects included were dental students of two dental colleges, patients attending the OPD of the two colleges, extracted teeth from different dental clinics (1000) of Kerala. Informed consents were obtained from the participants. Subjects whose second premolars were extracted were excluded. Gender predilection was determined among the 1500 (750 males and 750 females) participants of dental colleges.

\section{RESULTS}

Of the 2500 teeth evaluated,frequent cuspal pattern was 2 cusp variety $(52.8 \%)$, compared to 3 cusp form (44.4\%) (Table I, Fig. 1). One thousand five hundred subjects examined were equally selected for gender (750 females, 750 males) (Table II). The predominant groove patterns were U/ crescent shape (45-27\%) in 2-cusp variety and $Y$ pattern in 3-cusp variety (Table III, Fig 2). Gender prevalence is depicted in Fig 3. A total of 2500 teeth were examined (Subjects examined $=1500$, Extracted teeth $=1000)$.

\footnotetext{
* Department of Oral \& Maxillofacial Pathology, Azeezia College of Dental Sciences \& Research, Kerala, India.

** Department of Oral Medicine \& Radiology, PMS College of Dental Sciences \& Research, Kerala, India.
} 
Table I. Showing distribution of varieties of second premolar.

\begin{tabular}{lc}
\hline Teeth examined & $\mathbf{n}$ \\
\hline Teeth with two cusps & 1320 \\
Teeth with three cusps & 1110 \\
Missing teeth & 70 \\
Total & 2500 \\
\hline
\end{tabular}

\section{Premolar varieties}

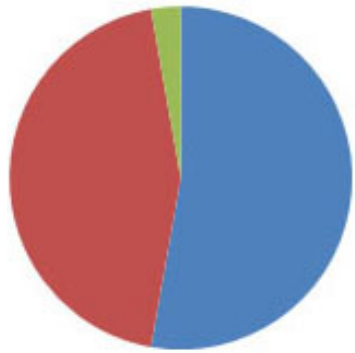

$$
\begin{aligned}
& \text { [ } 2 \text { cusp variety } \\
& {[52.8 \%]} \\
& \text { w cusp variety } \\
& {[44.4 \%]} \\
& \text { Missing II premolar } \\
& {[2.8 \%]}
\end{aligned}
$$

Fig. 1. Chart showing distribution of second premolar varieties.

Table II. Showing gender distribution of varieties of premolars.

\begin{tabular}{lc}
\hline Parameter & $\mathbf{n}$ \\
\hline Total female participants & 750 \\
Total male participants & 750 \\
Females with two cusp variety premolar & 390 \\
Females with three cusp variety premolar & 330 \\
Females with missing teeth & 25 \\
Males with two cusp variety premolar & 320 \\
Males with three cusp variety premolar & 390 \\
Males with missing teeth & 45 \\
\hline
\end{tabular}

Table III. Showing distribution of different groove patterns.

\begin{tabular}{lc}
\hline Pattern & $\mathbf{n}$ \\
\hline U shaped groove pattern & 1100 \\
H shaped groove pattern & 200 \\
Straight groove pattern & 20 \\
Y shaped groove pattern & 1100 \\
No groove pattern & 10 \\
\hline
\end{tabular}

We noticed the occurrence of the single variety (either 2-cusp or 3-cusp] bilaterally in most participants. A few subjects with two-cusp variety on one side and three cusp variety on the other side were also noticed $(20 \%)$.

\section{Groove patterns}
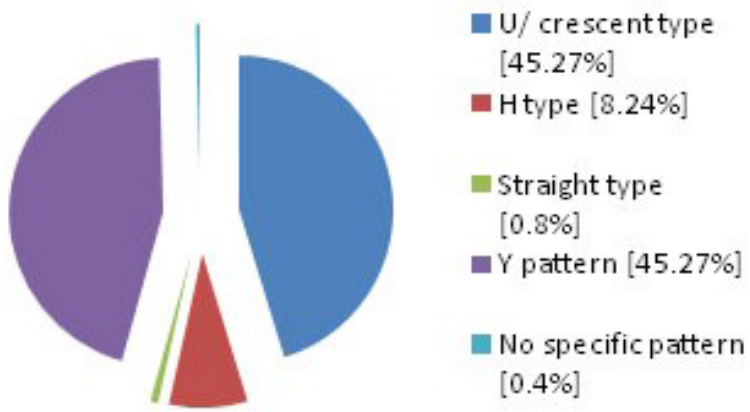

Fig. 2. Chart showing different groove patterns of second premolar.

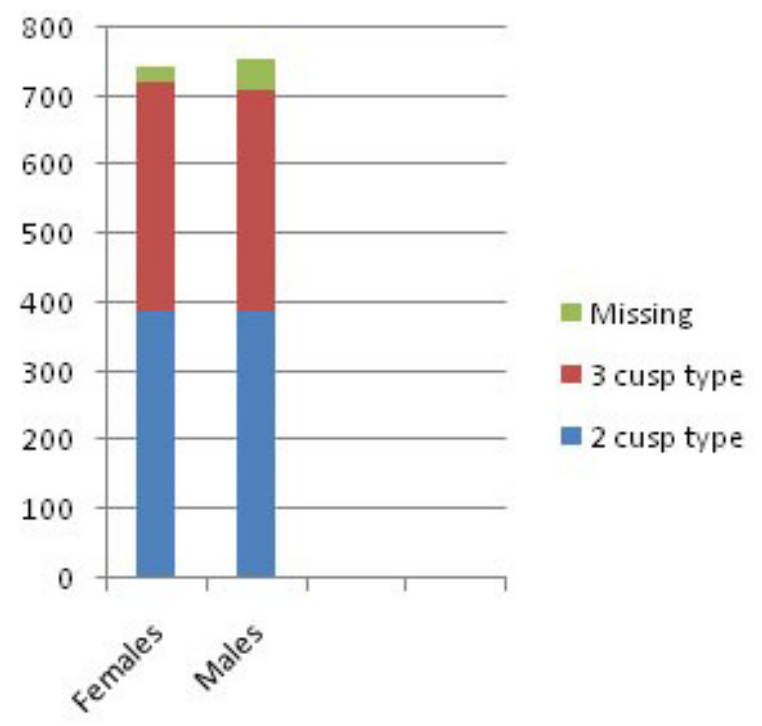

Fig. 3. Chart showing gender distribution.

\section{DISCUSSION}

The mandibular second premolar, the successor of deciduous second molar is comparatively larger than mandibular first premolar (Jordan et al., 1992; van beek, 1983). Although the buccal cusp of second premolar is not as pronounced, the mesiodistal measurement of crown and its general outline are similar to first premolar. The three-cusp variety appears more angular from the occlusal aspect. The two-cusp variety is more rounded from the occlusal aspect. Ash \& Nelson reported a higher prevalence for the 3-cusp pattern.

In mandibular second premolars, the lingual lobe/lobes are more developed making the cusp/ cusps longer (Loh, 1993). In three-cusp variety, mesiolingual cusp is larger than distolingual cusp and the buccal cusp is the largest (Mosharraf \& Hajian, 2004). A groove extends lingually between the two 
lingual cusps. Each cusp has well formed triangular ridges separated by deep developmental grooves. These grooves converge in the central pit and form $Y$ shape on the occlusal surface (Ash \& Nelson; Fuller et al.; Maji et al., 2008; Sharma, 1983). The central pit is located in the middle between buccal cusp ridge and lingual margin of the occlusal surface and slightly distal to the central point between mesial and distal marginal ridges.

In the two-cusp variety, one well-developed lingual cusp is directly opposite the buccal cusp in a lingual direction. The central groove travels in a mesiodistal direction. The groove may be straight, crescent/U or $\mathrm{H}$ types, with terminals in the mesial and distal fossae.

In this study a slight female predilection was seen for the two-cusp variety of second premolars and male predilection for three-cusp variety. U/crescent shape central groove pattern is more common than $\mathrm{H}$ pattern in the two-cusp variety.

The study of dental morphological characteristics and odontometry is important in anthropological research as it can provide information on the phylogenetic relationship between species, as well as variations and diversities within a population (Sharma). Furthermore, knowing common variations in dental anatomy and morphology about each individual tooth can help in performing some dental treatments. Therefore, the results of this anatomical study can be used in both anthropological researches and clinical aspects of dental sciences.

Further studies involving a larger population are expected to assess the gender predilection and prevalence rate more efficiently.

SUNIL, S. \& GOPAKUMAR, D. Prevalencia de las dos variantes de segundos premolares mandibulares en población Kerala. Int. J. Odontostomat., 6(3):375-377, 2012.

RESUMEN: Los segundos premolares mandibulares, aunque por lo general se clasifican como bicuspídeos, tienen dos tipos de variantes, de 2 y 3 cúspides. El objetivo de esta investigación fue determinar la prevalencia de las dos variedades de segundos premolares mandibulares en población Kerala, en el sur de la India. Esta investigación descriptiva se realizó en dos Universidades dentales de Kerala, India. En un total de 2500 segundos premolares mandibulares se examinaron las variaciones cuspídeas, patrones de surcos y la predilección según sexo. Se observó una ligera predilección [52,8\%] para la variedad de 2 cúspides. Las configuraciones oclusales de los segundos premolares más frecuentes fueron los patrones de surco en forma de media luna y en forma de $Y$ para las variantes de 2 y 3 cúspides, respectivamente.

PALABRAS CLAVE: segundo premolar inferior, forma cuspídea, patrones de surco.

\section{REFERENCES}

Ash, M. \& Nelson, S. Wheeler's dental anatomy, physiology, and occlusion. $8^{\text {th }}$ ed. Philadelphia, Elsevier Saunders, 2009. pp.239-61.

Fuller, J. L.; Denehy, G. E. \& Schulein, T. M. Concise dental anatomy and morphology. $4^{\text {th }}$ ed. lowa, University of lowa College of Dentistry, 2001. pp.86-98.

Jordan, R. E.; Abrams, L. \& Kraus, B. S. Kraus's dental anatomy and occlusion. St. Louis, Mosby Year Book, 1992.

Loh, H. S. Coronal morphology of the mandibular second premolar in the Singaporean Chinese. Aust. Dent. J., 38(4):283-6, 1993.

Ludwig, P. J. The mandibular second premolars: morphologic variation and inheritance. J. Dent. Res., 36(2):263-73, 1957.

Maji, J. Essentials of Oral Biology: Oral Anatomy, Histology,
Physiology and Embryology. New Delhi, CBS Publishers \& Distributors, 2008. pp.237-9.

Mosharraf, R. \& Hajian, F. Occlusal morphology of the mandibular first and second premolars in Iranian adolescents. Int. J. Dent. Anthropol., 5:10-4, 2004.

Sharma, J. C. Dental morphology and odontometry of the Tibetan immigrants. Am. J. Phys. Anthropol., 61(4):495505, 1983.

van beek, G. C. Dental morphology. Bristol, John Wright and Sons, 1983.

Correspondence to:

Dr. S. Sunil

Department of Oral \& Maxillofacial Pathology

Azeezia College of Dental Sciences \& Research

Kerala, INDIA

Email: drsunil74@yahoo.com

Received: 10-09-2012 Accepted: 26-11-2012 